\section{Minute ventilation during mask halothane anaesthesia in infants and children}

K.A. Brown MD, B. Bissonnette $M D$,

H. Holtby MD, S. Ein MD, B. Shandling MB
The pattern of respiration in infants during anaesthesia is not well documented. In this study, minute ventilation ( $M V)$ during elective mask halothane anaesthesia (HA) was measured during spontaneous ventilation in infants (Group I) and children (Group II). Airflow was measured with pneumotachography (\$0 Fleisch in Group I and \#I Fleisch in Group II). Analogue signals of pressure and flow were recorded on magnetic tape for off-line playback. The flow signal was mathematically integrated to volume. The surgical procedure was divided into three stages: $A, B$ and $C$ representing $H A$, surgical stimulation and emergence respectively. The pattern of respiration during spontaneous ventilation was described as tidal volume $\left(V T_{X}\right)$, respiratory frequency $\left(\sigma_{X}\right)$, mean inspiratory flow $\left(V T / T I_{X}\right)$, inspiratory duty cycle (TI/TTot ${ }_{X}$ ) where the subscript $x$ denoted the stage. Seven infants $(2.7 \pm 0.5 \mathrm{mo}, 5.8 \pm 0.5 \mathrm{~kg})$ and five children $(3.1 \pm 1.1 \mathrm{yr}, 15.8 \pm 1.7 \mathrm{~kg})$ were studied. There was no difference in $M V$ between Groups I and II. Halothane anaesthesia in both groups was characterized by rapid shallow breathing: $V T_{A}$ was lower in Group $I\left(2.90 \pm 0.8 \mathrm{ml} \cdot \mathrm{kg}^{-1}\right)$ than in Group II $\left(3.74 \pm 0.40 \mathrm{ml} \cdot \mathrm{kg}^{-1}\right)(P<0.05)$. Tidal volume was lower during anaesthesia than emergence in both groups $(P<0.05)$. There was no difference in $V T / T I_{X}$ between groups. The $V T / T I_{A}$ was lower than $V T / T I_{C}$ in Group $I(P$ $<0.05)$ but not in Group II. There was no intra or intergroup difference in TI/TTot between stages. We suggest that during $H A$ infants have a greater reduction in VT than children, which may predispose infants to hypercarbia during $H A$.

\section{Key words}

ANAESTHESIA: paediatric;

ANAESTHETICS, VOLATILE: halothane;

VENTILATION: anaesthetics, effect of.

From the Department of Anaesthesia, University of Toronto, The Hospital for Sick Children, Toronto, Canada.

Address correspondence to: Dr. Karen Brown, Department of Anaesthesia, Montreal Children's Hospital, 2300 Tupper St., Montreal, Quebec H3H 1P3.

Accepted for publication 6th October, 1992.
Les caractéristiques ventilatoires du nourisson pendant l'anesthésie sont mal définies. Au cours de la présente étude, la ventilation-minute $(M V)$ pendant l'anesthésie à l'halothane (HA) au masque pour chirurgie non urgente est mesurée sous ventilation spontanée chez des nourissons (groupe I) et des enfants (groupe II). Le débit respiratoire est mesuré par pneumotachographie (Fleisch $\# 0$ pour le groupe I, Fleisch \#1 pour le groupe II). L'affichage analogique de la pression et du débit est enregistré sur ruban magnétique pour analyse ultérieure. Le signal du débit respiratoire est intégré mathématiquement à celui du volume. Lintervention chirurgicale est divisée en trois stages : $A, B$, et $C$ lesquels représentent respectivement : $H A$, la stimulation chirugicale et la période du réveil. Les variables propres à la ventilation spontanée comprennent le volume courant $\left(V T_{X}\right)$, la fréquence respiratoire $(f x)$, le débit inspiratoire moyen $\left(V T / T I_{X}\right)$ et la durée du cycle inspiratoire (TI/ TTot $_{X}$ ) où lindice $X$ correspond au stage. Sept nourissons $(2,7$ $\pm 0,5$ mois, $5,8 \pm 0,5 \mathrm{~kg}$ ) et cing enfants $(3,1 \pm 1,1$ ans, $15,8 \pm 1,7 \mathrm{~kg}$ ) font partie de l'étude. On ne retrouve pas de différence de $M V$ entre les groupes I et II. L'anesthésie à l'halothane est caractérisée dans les deux groupes par une respiration superficielle rapide; le $V T_{A}$ est plus bas dans le groupe I (2,90 $\left.\pm 0,8 \mathrm{ml} \cdot \mathrm{kg}^{-1}\right)$ que dans le groupe II $(3,74 \pm 0,40$ $\left.\mathrm{ml} \cdot \mathrm{kg}^{-1}\right)(P<0,05)$. Le volume courant est moins élevé pendant l'anesthésie qu'à la période de réveil dans les deux groupes $(P<0,05)$. Il n'y a pas de différence pour le rapport $(V T)$ $\left.T I_{X}\right)$ entre les groupes. Le $V T / T I_{A}$ est inférieur au $V T / T I_{C}$ dans le groupe $I(P<0,05)$ mais non dans le groupe II. Il n'y a pas de différences à l'intérieur diun groupe ou entre les groupes pour le TI/TTot si on compare les stages. Ces résultats suggèrent que pendant $H A$, les nourissons subissent une plus grande réduction du VT que les enfants, ce qui peut prédisposer les nourissons à l'ypercarbie sous anesthésie spontanée à l'halothane.

Values for minute ventilation (MV) in spontaneously breathing anaesthetized infants are not well documented. This is, in part, because studies investigating MV during anaesthesia group infants with children and normalize ventilation data on a per $\mathrm{kg}$ basis. ${ }^{\mathrm{l}-4}$ The purpose of this study was to characterize and compare MV during 
halothane anaesthesia (HA) in infants and children. The tachypnoea of HA has been shown experimentally to be due to a central effect of halothane on the brainstem which reduces the duration of inspiration (TI). In addition, halothane-induced stimulation of irritant lung receptors may, through vagally mediated mechanisms, shorten TI. The aetiology of the shallow breathing characteristic of HA is thought to be multifactorial including: (1) the shortening of $\mathrm{TI}$; (2) a reduction in ventilatory drive and (3) an impairment in respiratory mechanics. ${ }^{5-7}$ One could hypothesize that halothane might affect the immature respiratory system of the infant differently from the adult and the child. We thought that a study of breathing patterns during $\mathrm{HA}$ in infants might be helpful to delineate the specific anaesthetic considerations of infants undergoing general anaesthesia.

\section{Methods}

The protocol was approved by the Ethics Committee on Human Experimentation and informed parental consent was obtained. Twelve healthy fasted children, ASA physical status I, undergoing elective herniorrhaphy were studied. Prematurity was considered an exclusion criterion. Patients were grouped according to age. Group I comprised infants aged 2 to $4 \mathrm{mo}$, and Group II comprised children aged 2 to $5 \mathrm{yr}$.

Premedication was not given. Anaesthesia was induced with thiopentone $\left(5 \mathrm{mg} \cdot \mathrm{kg}^{-1}\right)$ or halothane and was maintained with $70 \% \mathrm{~N}_{2} \mathrm{O}$ in oxygen at an inspired concentration of $2 \%$ in Group I and $2.5 \%$ in Group II. All patients received atropine $\left(0.02 \mathrm{mg} \cdot \mathrm{kg}^{-1}\right)$. Anaesthesia was delivered via a Mapleson D anaesthetic circuit using a fresh gas flow of $12 \mathrm{~L} \cdot \mathrm{min}^{-1}$. Resistance of the apparatus produced $1 \mathrm{~cm} \mathrm{H} \mathrm{H}_{2} \mathrm{O}$ at a $12 \mathrm{~L} \cdot \mathrm{min}^{-1}$ flow. In these patients, whose tracheas were not intubated, breathing was spontaneous through a modified Jackson Rees circuit with a scavenger attachment. An oropharyngeal airway was placed in all patients. An ilioinguinal field

LIST OF ABBREVIATIONS

The subscript $\mathrm{X}$ denotes the stage $\mathrm{A}, \mathrm{B}$ or $\mathrm{C}$ $f_{X}$ - Respiratory frequency

$\mathrm{MV}_{\mathrm{X}}-$ Minute ventilation $\left(\mathrm{VT} / \mathrm{TI}_{\mathrm{X}} \times \mathrm{TI} / \mathrm{TTot}_{\mathrm{X}}\right.$ $\times 60)$

$\mathrm{TE}_{\mathrm{X}}$ - Expiratory time

$\mathrm{TI}_{\mathrm{X}}$ - Inspiratory time

$\mathrm{TI} / \mathrm{TTot}_{\mathrm{X}}$ - Inspiratory duty cycle

TTot $_{\mathrm{X}}$ - total time of a respiratory cycle $\left(\mathrm{T}_{1}+\mathrm{T}_{\mathrm{E}}\right.$ $=\mathrm{T}_{\mathrm{Tot}} \mathrm{J}$

$\mathrm{VT}_{\mathrm{X}}$ - Tidal volume

$\mathrm{VT} / \mathrm{TI}_{\mathrm{X}}-$ Mean inspiratory flow

$\mathrm{P}_{\mathrm{ET}} \mathrm{CO}_{2}$ - End tidal partial pressure $\mathrm{CO}_{2}$ block with bupivicaine $(0.25 \%)$ was performed by the surgeon during closure of the surgical wound to provide postoperative analgesia. During emergence from anaesthesia, the nitrous oxide was discontinued and the child breathed $100 \%$ oxygen. The child was not disturbed during emergence from anaesthesia. Spontaneous movement of an extremity marked the end of the signal record.

Mouth pressure (Microswitch \#142PC050) and flow (Fleish \#0 (Group I) or \#1 (Group II) pneumotachograph Microswitch \#163PC1D36) were measured. Both pneumotachographs were calibrated with the two gas mixtures used during the surgical procedure namely (1) $70 \% \mathrm{~N}_{2} \mathrm{O}$ in oxygen and (2) 100\% oxygen and were linear over the range of flows observed. The flow calibration was verified with a volume calibration at the beginning and end of each study. The coefficient of variation for repeated volume measures was $2 \%$.

The signals were recorded on a Hewlett Packard fourchannel magnetic tape recorded for off-line playback through a 12-bit A to D board (Data Translation DT2801-A, Mississauga, Ontario, Canada). During playback, signals were sampled at $50 \mathrm{~Hz}$ and recorded on an IBM computer for off-line analysis (Anadat ${ }^{\oplus}$, RHTInfodat, Montreal, Canada). The flow signal was zero offset, drift corrected and mathematically integrated to volume. Signals underwent breath-by-breath analysis. Breaths showing evidence of a poor mask fit from the pressure and flow signals were discarded.

The surgical procedure was divided into three stages: A, B and C where stage A was pre-incision, stage B was during ligation and division of the hernia sac and stage $C$ was emergence. Stage $A$ represented steady state $\mathrm{HA}$, ten minutes after induction and before the confounding variable of painful surgical stimulation was introduced. Stage B introduced the confounding variable of a painful stimuli on the background of HA. Stage C represented recovery from $H A$. Since emergence spanned a period of about ten minutes, Stage $C$ was represented by data sampled during the minute preceding spontaneous movement of the child (Figure 1).

Values for $\mathrm{MV}_{\mathrm{X}}, \mathrm{VT}_{\mathrm{X}}, \mathrm{TI} / \mathrm{TT}_{\mathrm{T}}$ and $\mathrm{VT} / \mathrm{TI}_{\mathrm{X}}$ were expressed on a per $\mathrm{kg}$ basis, where the subscript $\mathrm{X}$ refers to the stage, A, B or C, TI/TTot is the inspiratory duty cycle, VT is tidal volume, VT/TI is the mean inspiratory flow.

It was not possible to coax fasted unpremedicated infants or children to breath quietly from the mask for control values of resting MV. Therefore, the predicted resting minute ventilation $\left(\mathrm{MRV}_{\mathrm{PRED}}\right)$ for each patient was derived from the Power Law prediction for minute ventilation in mammals: ${ }^{8}$

$\mathrm{MRV}_{\text {PRED }}=\mathrm{aBW}$ 


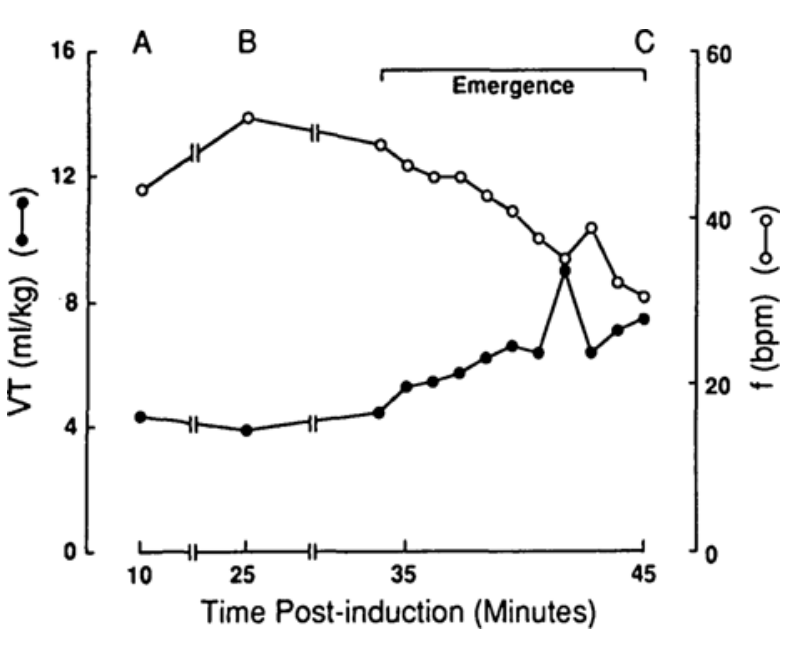

FIGURE I The course of a representative study. The changes in VT and $f$ in a representative patient during the course of the study are shown. Each data point represents the mean value of 30 s of representative data. The abscissa plots time post-induction of anaesthesia in minutes and relates it to the stage. The ordinate axes plot VT and $f$.

where the constant $a=379$, the exponent $b=0.8$ and $\mathrm{BW}$ is body weight in $\mathrm{kg}$. The ratio of $\mathrm{MV}_{\mathrm{X}} / \mathrm{MRV}_{\mathrm{PRED}}$ was calculated for each stage.

The predicted tidal volume ( $\mathrm{VT}_{\mathrm{PRED}}$ ) was taken to be the interspecies constant for mammals $\left(\mathrm{VT}_{\mathrm{PRED}}=7.69\right.$ $\left.\mathrm{ml} \cdot \mathrm{kg}^{-1}\right){ }^{9}$ The predicted value for the inspiratory duty cycle TI/TTot was taken to be the interspecies constant of $0.345 \pm 0.051$. $^{8}$

The predicted value for $\mathrm{VT} / \mathrm{TI}\left(\mathrm{VT} / \mathrm{TI}_{\mathrm{PRED}}\right)$ was derived from the power low prediction for VT/TI in mammals: ${ }^{9}$

$\log \mathrm{VT} / \mathrm{TI}=0.738 \log \mathrm{BW}+1.35$

$\mathrm{VT} / \mathrm{TI}=1.35 \mathrm{BW}^{0.74}$

where $\mathrm{BW}$ is the body weight in $\mathrm{kg}$.

\section{Statistical analysis}

Intergroup differences between $\mathrm{MV}_{\mathrm{x}} / \mathrm{MRV}_{\mathrm{PRED}}$ and control were assessed with Nonparametric Wilcoxon Ranked Sign test, where control $\mathrm{MV}_{\mathrm{X}} / \mathrm{MRV}_{\mathrm{PRED}}=1$. Intragroup differences were assessed with Nonparametric Wilcoxon ANOVA. ${ }^{10}$

\section{Results}

Seven infants in Group I ( $2.7 \pm 0.5 \mathrm{mo}, 5.8 \pm 0.5 \mathrm{~kg})$ and five children in Group II (3.1 $\pm 1.1 \mathrm{yr}, 15.8 \pm 1.7$ $\mathrm{kg}$ ) were studied. No patient moved with surgical incision.

The course of a representative study is shown in Figure 1. The abscissa plots time post-induction of anaesthesia and stage $A, B$ and $C$ and relates them to the value

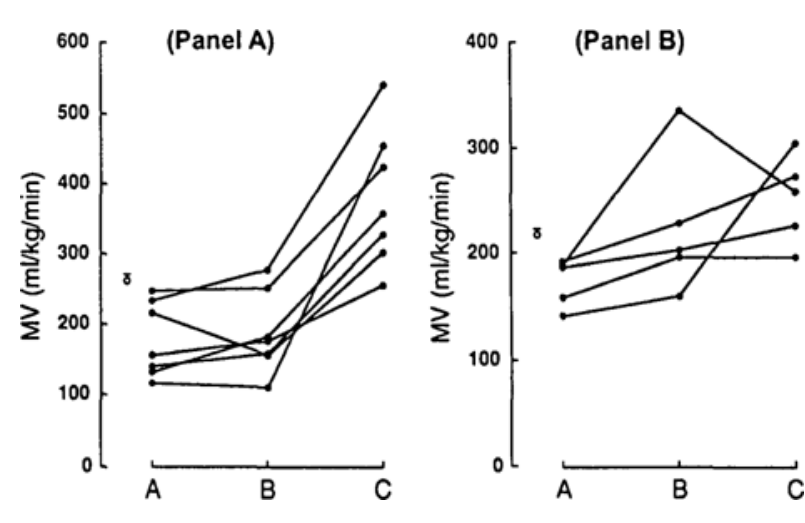

FIGURE 2 Values of $M V_{X}$ for individual patients during each stage in Group I (Panel A) and Group II (Panel B). MRV PRED for the Group ( $\mathrm{X} \pm \mathrm{SD})$ is indicated in the left hand margin of the figure.

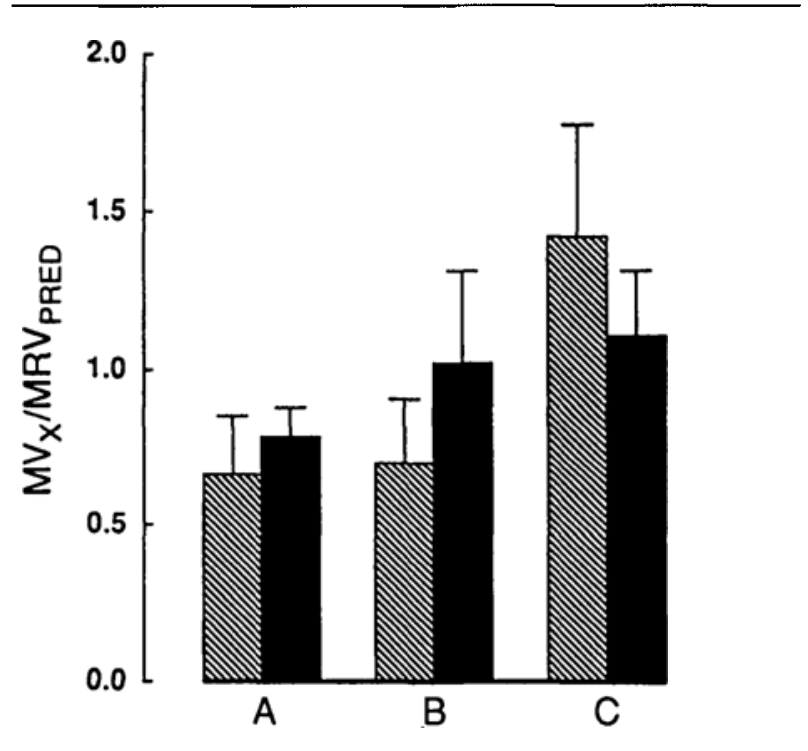

FIGURE 3 The ratio $M V_{X} / M R V_{\text {PRED }}$ for each stage in Group I (hatched) and Group II (solid). Standard deviations are shown. There was no statistical difference between groups.

for VT and $f$ on each ordinate axis. The $M R V_{\text {PRED }}$ in Group I was $267.03 \pm 5.03 \mathrm{ml} \cdot \mathrm{kg}^{-1} \cdot \mathrm{min}^{-1}$ and in Group Il was $218.41 \pm 4.05 \mathrm{ml} \cdot \mathrm{kg}^{-1} \cdot \mathrm{min}^{-1}$. The $\mathrm{MV}_{\mathrm{A}}$ in Group I was $177.7 \pm 53.9 \mathrm{ml} \cdot \mathrm{kg} \cdot{ }^{-1} \cdot \mathrm{min}^{-1}$, a value which was not different from the $\mathrm{MV}_{\mathrm{A}}$ in Group II of $173.7 \pm 22.0$ $\mathrm{ml} \cdot \mathrm{kg}^{-1} \cdot \mathrm{min}^{-1}$ (Table I, Figures 2, 3).

The $\mathrm{MV}_{\mathrm{B}}$ in Group I was $187.5 \pm 58.5 \mathrm{ml} \cdot \mathrm{kg}^{-1} \cdot \mathrm{min}^{-1}$ and was $224 \pm 66.9 \mathrm{ml} \cdot \mathrm{kg}^{-1} \cdot \mathrm{min}^{-1}$ in Group II. The $\mathrm{MV}_{\mathrm{C}}$ in Group I was $380.4 \pm 97.8 \mathrm{ml} \cdot \mathrm{kg}^{-1} \cdot \mathrm{min}^{-1}$ and in Group II was $248.9 \pm 41.6 \mathrm{ml} \cdot \mathrm{kg}^{-1} \cdot \mathrm{min}^{-1}$.

Table II summarizes the values for VT, $\mathrm{f}, \mathrm{VT} / \mathrm{TI}, \mathrm{TI} /$ TTot and TI during stages A, B and C. The value for 
TABLE I Demographic data for individual patients values for $M V_{P R E D}, M V_{X}$ and $M V_{X} / M R V_{P R E D}$ are given. An asterisk $(*)$ indicates intragroup statistical difference from stage $A(P<0.05)$. The symbol $(\ddagger)$ indicates intergroup statistical significance $(P<0.05)$

\begin{tabular}{|c|c|c|c|c|c|c|c|c|c|}
\hline \multirow[b]{2}{*}{ Pt. } & \multirow[b]{2}{*}{ Age } & \multirow[b]{2}{*}{$\begin{array}{l}W t \\
(\mathrm{~kg})\end{array}$} & \multirow[b]{2}{*}{$\begin{array}{l}M R V_{P R E D} \\
\left(\mathrm{ml} \cdot \mathrm{kg}^{-1}\right. \\
\left.\mathrm{min}^{-1}\right)\end{array}$} & \multicolumn{2}{|l|}{ Stage $A$} & \multicolumn{2}{|l|}{ Stage $B$} & \multicolumn{2}{|l|}{ Stage $C$} \\
\hline & & & & $\begin{array}{l}M V \\
\left(\mathrm{ml} \cdot \mathrm{kg}^{-l}\right. \\
\left.\mathrm{min}^{-1}\right)\end{array}$ & $\begin{array}{l}M V_{A} / \\
M R V_{\text {PRED }}\end{array}$ & $\begin{array}{l}M V \\
\left(\mathrm{ml} \cdot \mathrm{kg}^{-1}\right. \\
\left.\mathrm{min}^{-1}\right)\end{array}$ & $\begin{array}{l}M V_{B} / \\
M R V_{P R E D}\end{array}$ & $\begin{array}{l}M V \\
\left(m l \cdot k g^{-1}\right. \\
\left.\min ^{-l}\right)\end{array}$ & $\begin{array}{l}M V_{C} \\
M R V_{\text {PRED }}\end{array}$ \\
\hline Group I & (mo) & & & & & & & & \\
\hline 1 & 3.0 & 6.6 & 259.85 & 156.80 & 0.60 & 175.08 & 0.67 & 256.11 & 0.99 \\
\hline 2 & 3.0 & 6.0 & 264.86 & 140.70 & 0.53 & 157.90 & 0.60 & 327.70 & 1.24 \\
\hline 3 & 2.0 & 5.0 & 274.69 & 247.60 & 0.90 & 253.00 & 0.92 & 424.80 & 1.55 \\
\hline 4 & 3.0 & 5.8 & 266.66 & 216.50 & 0.81 & 156.20 & 0.59 & 302.60 & 1.14 \\
\hline 5 & 3.0 & 5.9 & 265.75 & 131.20 & 0.49 & 181.83 & 0.68 & 358.50 & 1.35 \\
\hline 6 & 3.0 & 5.2 & 272.55 & 234.90 & 0.86 & 278.10 & 1.02 & 539.00 & 1.98 \\
\hline 7 & 2.0 & 6.0 & 264.86 & 116.20 & 0.44 & 110.40 & 0.42 & 454.20 & 1.72 \\
\hline$x$ & 2.70 & 5.80 & 267.03 & 177.70 & 0.66 & 187.50 & 0.70 & $380.40^{*}$ & $1.42^{*}$ \\
\hline$\pm \mathrm{SD}$ & 0.52 & 0.54 & 5.03 & 53.90 & 0.19 & 58.50 & 0.21 & 97.80 & 0.35 \\
\hline Group II & $(y r)$ & & & & & & & & \\
\hline 1 & 2.0 & 15.0 & 220.51 & 186.50 & 0.85 & 202.30 & 0.92 & 225.45 & 1.02 \\
\hline 2 & 2.5 & 16.0 & 217.68 & 192.26 & 0.88 & 228.10 & 1.05 & 272.55 & 1.25 \\
\hline 3 & 2.0 & 16.0 & 217.68 & 159.33 & 0.73 & 196.27 & 0.90 & 195.78 & 0.90 \\
\hline 4 & 3.5 & 14.0 & 223.57 & 188.32 & 0.84 & 336.15 & 1.50 & 257.37 & 1.15 \\
\hline 5 & 4.5 & 18.0 & 212.61 & 141.89 & 0.67 & 160.16 & 0.75 & 303.45 & 1.43 \\
\hline$x$ & 3.1 & 15.8 & 218.41 & 173.70 & 0.79 & 224.00 & $1.02^{*}$ & $248.90 * \ddagger$ & $1.15^{*}$ \\
\hline$\pm \mathrm{SD}$ & 1.1 & 1.7 & 4.05 & 22.00 & 0.09 & 66.90 & 0.29 & 41.60 & 0.21 \\
\hline
\end{tabular}

$\mathrm{VT}_{\mathrm{A}}$ in Group I was $2.9 \pm 0.80 \mathrm{ml} \cdot \mathrm{kg}^{-1}$. In Group I $\mathrm{VT}_{\mathrm{B}}$ was unchanged $\left(2.9 \pm 0.90 \mathrm{ml} \cdot \mathrm{kg}^{-1}\right)$. In this group respiratory frequency $\mathrm{f}_{\mathrm{B}}$ increased to $68 \pm 14 \mathrm{bpm}(P$ $<0.05$ ). During $\mathrm{HA}, \mathrm{VT}_{\mathrm{A}}$ and $\mathrm{VT}_{\mathrm{B}}$ were higher in Group II with the value of $\mathrm{VT}_{\mathrm{A}}=3.74 \pm 0.40 \mathrm{ml} \cdot \mathrm{kg}^{-1}(P$ $<0.05$ ). During emergence from HA, VT increased in all patients in both groups such that in Group $\mathrm{I} \mathrm{VT}_{\mathrm{C}}$ was $6.6 \pm 1.5 \mathrm{ml} \cdot \mathrm{kg}^{-1}$ and in Group II $\mathrm{VT}_{\mathrm{C}}$ was 7.1 $\pm 1.4 \mathrm{ml} \cdot \mathrm{kg}^{-1}(P<0.05)$ (Figure 4).

The VT/TI PRED in Group I was $14.15 \pm 0.39$ $\mathrm{ml} \cdot \mathrm{kg}^{-1} \cdot \mathrm{sec}^{-1}$ and in Group II was $10.88 \pm 0.26$ $\mathrm{ml} \cdot \mathrm{kg}^{-1} \cdot \mathrm{sec}^{-1}$. In Group I the values of VT/ $\mathrm{TI}_{\mathrm{A}}$ and $\mathrm{VT} / \mathrm{TI}_{\mathrm{B}}$ were $8.0 \pm 1.94 \mathrm{ml} \cdot \mathrm{kg}^{-1} \cdot \mathrm{sec}^{-1}$ and $8.4 \pm 2.10$ $\mathrm{ml} \cdot \mathrm{kg}^{-1} \cdot \mathrm{sec}^{-1}$ respectively. During emergence in Group I VT/ $\mathrm{TI}_{\mathrm{C}}$ increased in all infants to a mean of $16.7 \pm$ $4.7 \mathrm{ml} \cdot \mathrm{kg}^{-1} \cdot \mathrm{sec}^{-1}(P<0.05)$. In Group II the value for $\mathrm{VT} / \mathrm{TI}_{\mathrm{A}}$ tended to be lower than $\mathrm{VT} / \mathrm{TI}_{\mathrm{C}}$ but the difference did not reach statistical significance. There was no difference in the ratio TI/TTot between or within groups.

\section{Discussion}

Comparison of MV during Stage A (HA) and Stage C (emergence) showed that MV was lower $(P<0.05)$ during HA in both infants and children. This finding is consistent with observations during $\mathrm{HA}$ in adults and

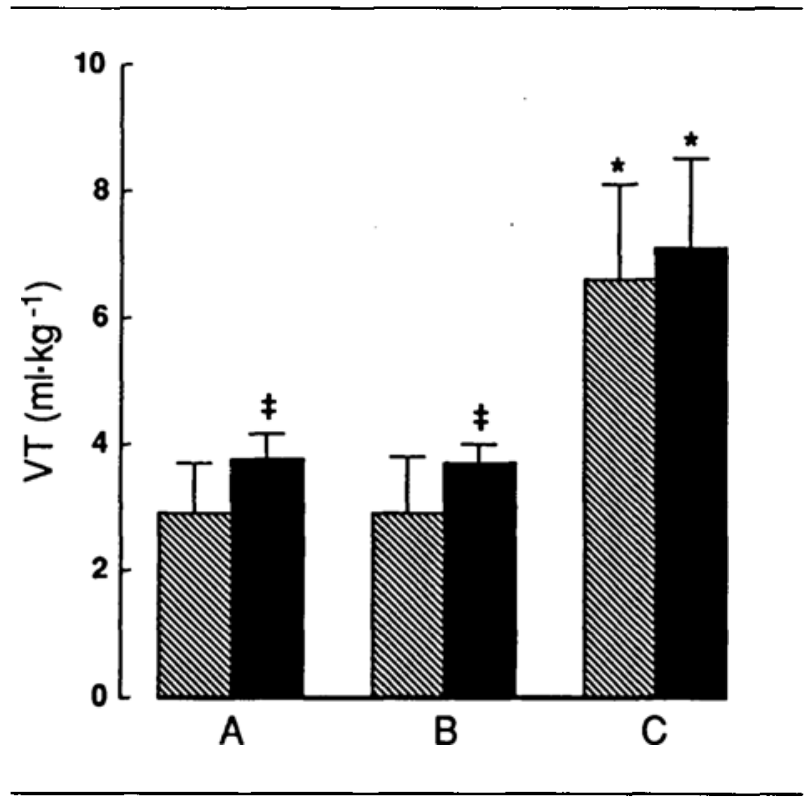

FIGURE 4 This histogram $(X \pm S D)$ summarizes group values for $\mathrm{VT}_{\mathrm{X}}$ during $\mathrm{HA}$ and recovery in both groups. During $\mathrm{HA} \mathrm{VT}_{\mathrm{A}}$ and $\mathrm{VT}_{\mathrm{B}}$ were lower than $\mathrm{VT}_{\mathrm{C}}$ in both groups $(P<0.05)$. During $\mathrm{HA}$ $\mathrm{VT}_{\mathrm{A}}$ and $\mathrm{VT}_{\mathrm{B}}$ were lower in Group I (hatched) than in Group II (solid). $(P<0.05)$ There was no difference in $\mathrm{VT}_{\mathrm{C}}$ between groups. The asterisk $\left(^{*}\right)$ indicates intragroup statistical difference from stage $A$ $(P<0.05)$. The symbol $(\ddagger)$ indicates intergroup statistical difference from Group I $(P<0.05)$. 
TABLE II Values for $\mathrm{VT}_{\mathrm{X}}, \mathrm{F}_{1}, \mathrm{VT} / \mathrm{TI}_{\mathrm{X}}, \mathrm{TI} / \mathrm{TTot}_{\mathrm{x}}$, and $\mathrm{T}_{1}$. The asterisk $\left(^{*}\right)$ indicates intragroup statistical difference from stage $\mathrm{A}(P<0.05)$. The symbol $(\ddagger)$ indicates intergroup statistical difference from group $I(P<0.05)$

\begin{tabular}{|c|c|c|c|c|c|c|c|c|c|c|c|c|c|c|c|}
\hline & \multicolumn{5}{|l|}{ Stage A } & \multicolumn{5}{|l|}{ Stage B } & \multicolumn{5}{|l|}{ Stage $C$} \\
\hline & $\begin{array}{l}V T \\
\left(\mathrm{ml} \cdot \mathrm{kg}^{-1}\right)\end{array}$ & $\underset{(b p m)}{f}$ & $\begin{array}{l}V T / T I \\
\left(\mathrm{ml} \cdot \mathrm{kg}^{-1}\right. \\
\left.\mathrm{min}^{-1}\right)\end{array}$ & $\begin{array}{l}\text { TII } \\
\text { TTot }\end{array}$ & $\begin{array}{l}T I \\
(s)\end{array}$ & $\begin{array}{l}V T \\
\left(\mathrm{ml} \cdot \mathrm{kg}^{-1}\right)\end{array}$ & $\underset{(b p m)}{f}$ & $\begin{array}{l}V T / T I \\
\left(\mathrm{ml} \cdot \mathrm{kg}^{-l} .\right. \\
\left.\mathrm{min}^{-i}\right)\end{array}$ & $\begin{array}{l}\text { TI/ } \\
\text { TTot }\end{array}$ & $\begin{array}{l}T I \\
(s)\end{array}$ & $\begin{array}{l}V T \\
\left(\mathrm{ml} \cdot \mathrm{kg}^{-1}\right)\end{array}$ & $\underset{(b p m)}{f}$ & $\begin{array}{l}V T / T I \\
\left(\mathrm{ml} \cdot \mathrm{kg}^{-1}\right. \\
\left.\mathrm{min}^{-1}\right)\end{array}$ & $\begin{array}{l}\text { TII } \\
\text { TTot }\end{array}$ & $\begin{array}{l}T I \\
(s)\end{array}$ \\
\hline \multicolumn{16}{|c|}{ Group I } \\
\hline 1 & 2.20 & 61.0 & 6.5 & 0.40 & 0.40 & 2.40 & 72.0 & 7.7 & 0.38 & 0.31 & 7.30 & 35.0 & 9.8 & 0.44 & 0.74 \\
\hline 2 & 2.80 & 51.0 & 6.2 & 0.34 & 0.40 & 2.50 & 64.0 & 8.1 & 0.32 & 0.30 & 4.70 & 70.0 & 14.3 & 0.38 & 0.33 \\
\hline 3 & 3.10 & 80.0 & II.6 & 0.36 & 0.26 & 2.80 & 90.0 & 11.0 & 0.38 & 0.26 & 5.80 & 73.0 & 18.6 & 0.38 & 0.31 \\
\hline 4 & 3.20 & 69.0 & 8.6 & 0.42 & 0.37 & 2.60 & 83.0 & 6.2 & 0.42 & 0.31 & 5.00 & 61.0 & 13.9 & 0.36 & 0.26 \\
\hline 5 & 2.50 & 53.0 & 6.8 & 0.32 & 0.37 & 3.10 & 60.0 & 9.5 & 0.32 & 0.32 & 8.10 & 44.0 & 19.6 & 0.31 & 0.41 \\
\hline 6 & 4.50 & 51.0 & 9.3 & 0.42 & 0.48 & 4.80 & 53.0 & 10.8 & 0.43 & 0.50 & 8.60 & 63.0 & 24.3 & 0.37 & 0.35 \\
\hline 7 & 2.10 & 55.0 & 7.1 & 0.27 & 0.30 & 2.00 & 54.0 & 5.6 & 0.33 & 0.29 & 6.50 & 70.0 & 16.6 & 0.46 & 0.39 \\
\hline $\mathrm{x}$ & 2.90 & 60.1 & 8.0 & 0.36 & 0.37 & 2.90 & $68.0^{*}$ & 8.4 & 0.37 & 0.37 & $6.60^{*}$ & 59.4 & $16.7^{*}$ & 0.39 & 0.40 \\
\hline$\pm \mathrm{SD}$ & 0.80 & 11.0 & 1.9 & 0.06 & 0.07 & 0.90 & 14.0 & 2.1 & 0.04 & 0.08 & 1.50 & 14.5 & 4.7 & 0.05 & 0.16 \\
\hline \multicolumn{16}{|c|}{ Group II } \\
\hline 1 & 4.30 & 44.0 & 8.9 & 0.35 & 0.48 & 3.90 & 52.0 & 8.4 & 0.40 & 0.47 & 7.40 & 31.0 & 10.4 & 0.36 & 0.71 \\
\hline 2 & 3.90 & 49.0 & 9.9 & 0.32 & 0.37 & 4.00 & 57.0 & 10.6 & 0.36 & 0.38 & 6.90 & 40.0 & 14.0 & 0.32 & 0.40 \\
\hline 3 & 3.80 & 42.0 & 8.7 & 0.31 & 0.44 & 3.80 & 53.0 & 10.7 & 0.31 & 0.35 & 6.00 & 33.0 & 7.9 & 0.41 & 0.76 \\
\hline 4 & 3.30 & 58.0 & 8.5 & 0.37 & 0.38 & 3.70 & 90.0 & 14.9 & 0.38 & 0.25 & 5.80 & 43.0 & 12.3 & 0.34 & 0.46 \\
\hline 5 & 3.40 & 42.0 & 6.3 & 0.37 & 0.53 & 3.30 & 49.0 & 6.6 & 0.40 & 0.50 & 9.40 & 32.0 & 11.7 & 0.43 & 0.73 \\
\hline$x$ & $3.74 \ddagger$ & $47.0 \ddagger$ & 8.5 & 0.40 & 0.44 & $3.70 \ddagger$ & $60.2^{*}$ & 10.2 & 0.37 & 0.39 & $7.10^{*}$ & $37.8 \ddagger$ & 11.3 & 0.37 & 0.61 \\
\hline$\pm \mathrm{SD}$ & 0.40 & 06.8 & 1.3 & 0.08 & 0.07 & 0.30 & 16.9 & 3.1 & 0.04 & 0.10 & 1.40 & $5.5^{+}$ & 2.3 & 0.05 & 0.17 \\
\hline
\end{tabular}

in children. The value for $\mathrm{MV}_{\mathrm{A}}$ in Group I (177.70 \pm $\left.53.90 \mathrm{ml} \cdot \mathrm{kg}^{-1} \cdot \mathrm{min}^{-1}\right)$ was not different from $\mathrm{MV}_{\mathrm{A}}$ in Group II $\left(173.7 \pm 22.0 \mathrm{ml} \cdot \mathrm{kg}^{-1} \cdot \mathrm{min}^{-1}\right)$. Reported values for MV during HA range from 106 to 120 $\mathrm{ml} \cdot \mathrm{kg}^{-1} \cdot \mathrm{min}^{-1} \cdot{ }^{1-4}$ However, it is difficult to compare our results with these studies because of differences in methodology and important aspects of study design, namely the use of premedication and different depths of anaesthesia. In addition studies in the literature involved children of dissimilar ages which presents a problem when ventilation data is normalized on a per $\mathrm{kg}$ basis.

Extensive investigations have shown that when normalized to body weight, small mammals have a higher metabolic rate than larger mammals. Since alveolar ventilation is closely coupled to metabolic rate, it follows that, resting minute ventilation, when normalized to body weight, is higher in infants than in adults. " The validity of our value of $M R V_{\text {PRED }}$ in infants (Group I) is supposed by the work of Haddad ${ }^{12}$ who measured MV in sleeping infants and found an instantaneous MV of 20-25 $\mathrm{ml} \cdot \mathrm{sec}^{-1}$ which in a $5 \mathrm{~kg}$ two-to-three-month-old infant would be about $240-300 \mathrm{ml} \cdot \mathrm{kg}^{-1} \cdot \mathrm{min}^{-1}$. This range is in good agreement with our $\mathrm{MRV}_{\text {PRED }}$ of $267.03 \pm 5.03$ $\mathrm{ml} \cdot \mathrm{kg}^{-1} \cdot \mathrm{min}^{-1}$ in Group I. No comparable values for resting minute ventilation in sleeping children are available to validate $M V_{\text {PRED }}$ in Group II of $218.41 \pm 4.05$ $\mathrm{ml} \cdot \mathrm{kg}^{-1} \cdot \mathrm{min}^{-1}$. It was expected that $\mathrm{MV}_{\mathrm{X}}$ should be higher in Group I than Group II. This expectation was only seen in Stage $\mathrm{C}(P<0.05)$. During $\mathrm{HA}, \mathrm{MV}_{\mathrm{A}}$ was similar in both groups.

The ratio $M V_{X} / M R V_{\text {PRED }}$ was used to factor in the difference in $M R V_{\text {PRED }}$ when normalized to body weight. It is noteworthy that during emergence $M V_{C} / M R V_{\text {PRED }}$ exceeded unity in both groups. This may have indicated the influence of painful stimuli on minute ventilation. $\mathrm{MV}_{\mathrm{X}} / \mathrm{MRV}_{\mathrm{PRED}}$ was lower during $\mathrm{HA}$ than emergence in both groups $(P<0.05)$. There was no intergroup difference although the ratio $\mathrm{MV}_{\mathrm{A}} / \mathrm{MRV}_{\mathrm{PRED}}$ of $0.66 \pm$ 0.19 in Group I was lower than the value of $0.79 \pm$ 0.09 in Group II.

Discussion of the effect of halothane on MV must consider the concentration of halothane used. Clinical experience had shown that infants (Group I) required an inspired halothane concentration of $2 \%$ and the children (Group II) required an inspired halothane concentration of $2.5 \%$ for herniorrhaphy. The minimum alveolar concentration (MAC) for halothane in infants aged two to three months ranges from $1.08 \%$ to $1.2 \%{ }^{13-15}$ whereas MAC for halothane in children two to five years ranges from 0.91 to $1.07 \% .^{13,15}$ Therefore, for Group I the halothane MAC multiple (\% halothane/MAC) was around 1.7. For Group II the halothane MAC multiple was 
around 2.6. Consideration of the slower uptake of halothane in Group II, which at ten minutes after induction of anaesthesia would give an expired to inspired halothane concentration $\left(\mathrm{F}_{\mathrm{E}} / \mathrm{F}_{\mathrm{l}}\right)$ ratio of 0.6 in Group $\mathrm{II}$ and 0.7 in Group I, would lower the Stage A MAC multiple to 1.6 and 1.2 respectively. ${ }^{16}$ Our study design might have biased Group II to have a deeper plane of anaesthesia and a greater degree of respiratory depression.

Stage B introduced the confounding variable of surgical stimulation; it resulted in an increase in $\mathrm{MV}_{\mathrm{B}}$ / $\mathrm{MRV}_{\text {PRED }}$ in Group II $(P<0.05)$ but no increase in Group I.

Analysis of MV into its components of tidal volume and frequency showed several features. Firstly, in Stage $C$ there was no difference in $\mathrm{VT}_{C}$ between groups and in both groups $\mathrm{VT}_{\mathrm{C}}$ approximated the predicted VT of $7.69 \mathrm{ml} \cdot \mathrm{kg}^{-1} \cdot{ }^{9}$ Both groups showed a reduction in VT during HA (Stage A) $(P<0.05)$. Neither group showed an increase in $\mathrm{VT}_{\mathrm{B}}$ during surgical stimulation. However, $\mathrm{VT}_{\mathrm{A}}$ and $\mathrm{VT}_{\mathrm{B}}$ were lower in infants $\left(2.9 \mathrm{ml} \cdot \mathrm{kg}^{-1}\right)$ than in children $\left(3.7 \mathrm{ml} \cdot \mathrm{kg}^{-1}\right)(P<0.05)$. The lower VT during HA in Group I may have clinical importance suggesting a substantive predisposition for carbon dioxide retention in infants. As expected, respiratory frequency was higher in infants than children during Stage $A$ and Stage C $(P<0.05)$. Only Group II showed an increase in respiratory frequency during HA $(P<0.05)$. During maximal surgical stimulation both groups showed an increase in $\mathrm{f}_{\mathrm{B}}(P<0.05)$.

Minute ventilation has also been expressed as the product of mean inspiratory flow (VT/TI) and the ratio TI/ TTot:

\section{$\mathrm{MV}=\mathrm{VT} / \mathrm{TI} \times \mathrm{TI} / \mathrm{TT}$ Tot.}

such that VT/TI has been interpreted as an index of central drive and TI/TTot is an index of timing. ${ }^{7,17,18}$

The inspiratory duty cycle (TI/ TTot) has been used as an index of the switching mechanism between the medullary inspiratory and expiratory motoneurons. ${ }^{7,17,18}$ The values of TI/ TTot ${ }_{A}$ in Groups I and II $(0.37 \pm 0.06$ and $0.34 \pm 0.03$ respectively) were not different and were within one standard deviation of the interspecies constant of $0.345 \pm 0.051 .^{5}$

Mean inspiratory flow (VT/TI) has been used as a variable of ventilatory drive. In Group II there was no difference in $\mathrm{VT} / \mathrm{TI}_{\mathrm{X}}$ in any stage suggesting that ventilatory drive was not depressed during HA. This finding is curious since it agrees with a study in adults which suggested that methoxyflurane did not depress ventilatory drive - that is that the neural output of the medullary ventilatory centre was not depressed during methoxyflurane anaesthesia. ${ }^{19}$ In Group I VT/ $\mathrm{TI}_{\mathrm{A}}$ was lower than $\mathrm{VT} / \mathrm{TI}_{\mathrm{C}}(P<0.05)$, suggesting that in contrast to Group
II experienced a decrease in ventilatory drive during HA. The VT/TI can also be influenced by changes in respiratory impedance which affect the flow rate generated for a given level of respiratory drive. Further studies which account for the effect of HA on respiratory mechanics are indicated to define the effect of halothane on ventilation in infants.

\section{Acknowledgements}

Supported by Physicians Services Incorporated. Many thanks to the Day Care Surgery nursing staff for their cooperation and support. We would like to thank Dr. C. Macarthur for advice regarding the statistical analysis and Mrs. R. Cacolyris for her expertise in preparing the manuscript.

\section{References}

1 Wren WS, Allen P, Synnot A, O'Keeffe D, O'Gniofa P. Effects of halothane, isoflurane and enflurane on ventilation in children. Br J Anaesth 1987; 59: 399-409.

2 Murat I, Chaussain M, Hamza J, Saint-Maurice C. The respiratory effects of isoflurane, enflurane and halothane in spontaneously breathing children. Anaesthesia 1987; 42: 711-8.

3 Lindahl SGE, Hulse MG, Hatch DJ. Ventilation and gas exchange during anaesthesia and surgery in spontaneously breathing infants and children. Br J Anaesth 1984; 56: 121-8.

4 Lindahl SGE, Yates AP, Hatch DJ. Respiratory depression in children at different end tidal halothane concentrations. Anaesthesia 1987; 42: 1267-75.

5 Ing $A B$, deGoede $J$, Olievier CN, Quanjer $H$. Sites of action of halothane on respiratory pattern and ventilatory response to CO2 in Cats. Anesthesiology 1982; 57: 389-98.

6 Tabatabai M, Kitahata LM, Yuge O, Matsumoto M, Collins $J G$. Effects of halothane on medullary inspiratory neurons of the cat. Anesthesiology 1987; 66: 176-80.

7 Milic-Emili J, Zin WA. Relationship between neuromuscular respiratory drive and ventilatory output. In: Handbook of Physiology. The Respiratory System Chp 49. Bethesda MD: Am Physiol Soc 1986; 35: 631-46.

8 Stahl WR. Scaling of respiratory variables in mammals. J Appl Physiol 1967; 22: 453-60.

9 Boggs DF, Tenney SM. Scaling respiratory pattern and respiratory "drive". Respir Physiol 1984; 58: 245-51.

10 Cohen J. Statistical Power Analysis For The Behavioral Sciences (2nd ed.). New Jersey: Lawrence Erlbaum Associates Publishers, 1988.

11 Radford EP. Ventilation standards for use in artificial respiration. J Appl Physiol 1955; 7: 451-60.

12 Haddad GG, Epstein MAF, Leistner HL, Marino PA, Mellins $R B$. Maturation of ventilation and ventilatory pat- 
tern in normal sleeping infants. J Appl Physiol 1979; 46: 998-1002.

13 Gregory GA, Eger EL, Munson ES. The relationship between age and halothane requirement in man. Anesthesiology 1969; 30: 488-91.

14 Lerman J, Robinson S, Willis MM, Gregory GA.

Anesthetic requirements for halothane in young children 0-1 month and 1-6 months of age. Anesthesiology 1983; 59: 421-4.

15 Nicodemus HF, Nassini-Rahimi C, Bachman L, Smith TC. Median effective doses (ED50) of halothane in adults and children. Anesthesiology 1969; 31: 344-8.

16 Brandom $B W$, Brandom $R B$, Cook $D R$. Uptake and distribution of halothane in infants: in vivo measurements and computer simulations. Anesth Analg 1983; 62: 404-10.

17 Milic-Emili J, Grunstein MM. Drive and timing components of ventilation. Chest 1976; 70: 131-3.

18 Benchetrit G, Shea SA, Baconnier PF, Dinh TP, Guz A. In favour of an "holistic" approach to the analysis of the pattern of breathing. In: GD Swanson, FS Grodlins, RL Hughson (Eds.). Respiratory Control A Modeling Perspective. Plenum Press 1989: 417-21.

19 Derrene JP, Coutur J, Iscoe S, Whitelaw WA, Milic-Emili $J$. Occlusion pressures in men rebreathing $\mathrm{CO}_{2}$ under methoxyflurane anaesthesia. J Appl Physiol 1976; 40: 805-14. 